\title{
Estimated Ground-Water Discharge by Evapotranspiration, Ash Meadows Area, Nye County, Nevada, 1994
}

By William D. Nichols, Randell J. Laczniak, Guy A. DeMeo, and Timothy R. Rapp

U.S. GEOLOGICAL SURVEY

Water-Resources Investigations Report 97-4025

Prepared in cooperation with the U.S. DEPARTMENT OF ENERGY, OFFICE OF ENVIRONMENTAL RESTORATION AND WASTE MANAGEMENT NEVADA OPERATIONS OFFICE, under Interagency Agreement DE-Al08-91NV11040

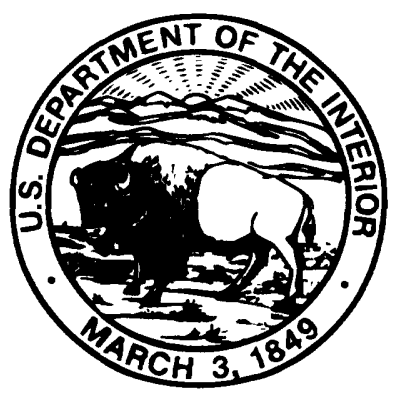

Carson City, Nevada 1997 


\title{
U.S. DEPARTMENT OF THE INTERIOR BRUCE BABBITT, Secretary
}

\author{
U.S. GEOLOGICAL SURVEY \\ GORDON P. EATON, Director
}

Any use of trade names in this publication is for descriptive purposes

only and does not constitute endorsement by the U.S. Government

For additional information write to:

District Chief

U.S. Geological Survey

333 West Nye Lane, Room 203

Carson City, NV 89706-0866

email: usgsinfo_nv@usgs.gov
Copies of this report can be purchased from:

U.S. Geological Survey

Branch of Information Services

Box 25286

Denver, CO 80225-0286 


\section{CONTENTS}

Abstract

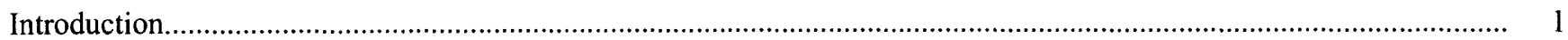

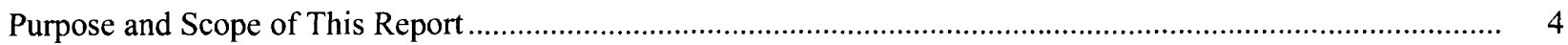

Study Area

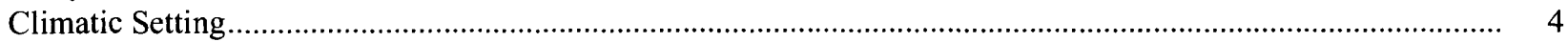

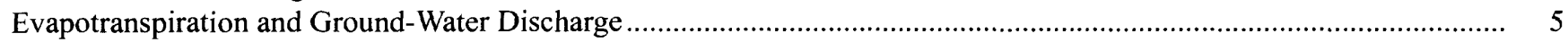

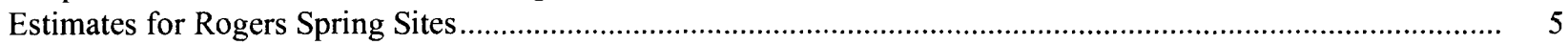

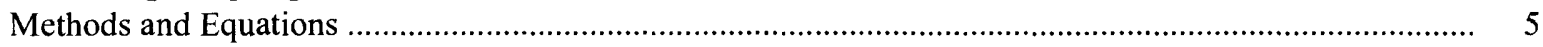

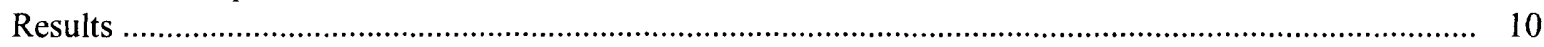

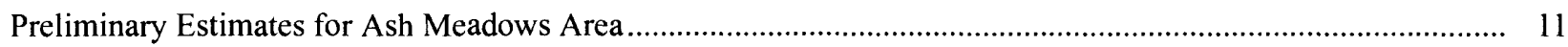

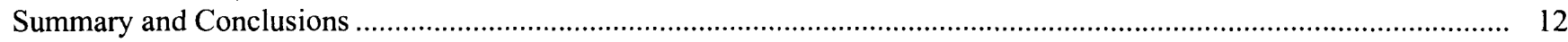

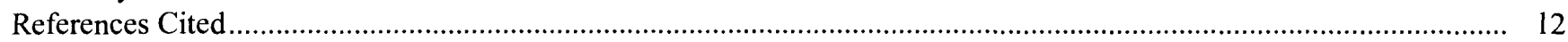

\section{FIGURES}

1. Map of southern Nevada and southeastern California showing location of Ash Meadows, Nevada Test Site,

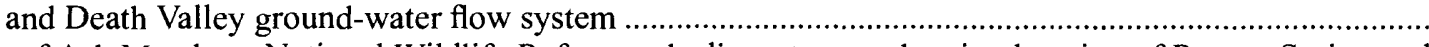

2. Map of Ash Meadows National Wildlife Refuge and adjacent areas showing location of Rogers Spring and field study sites.

3-5. Graphs showing data for Rogers Spring Sites 1 and 2, 1994:

3. Daily evapotranspiration and daily mean net radiation at Site 1

4. Daily evapotranspiration and daily mean net radiation at Site 2

5. Monthly mean daily evapotranspiration at Sites 1 and 2 ......

\section{TABLES}

1. Climatic data for U.S. Weather Service stations near Ash Meadows and U.S. Geological Survey stations at Rogers Spring.

2. Daily evapotranspiration at Rogers Spring Site 1, 1994

3. Daily evapotranspiration at Rogers Spring Site 2, 1994

4. Annual total and annual mean, maximum, and minimum daily evapotranspiration, Rogers Spring Sites 1 and 2, 1994.

5. Estimated discharge of shallow ground water by evapotranspiration from marshes and saltgrass areas, Ash Meadows, 1994. 


\begin{tabular}{rrrl}
\hline Multiply & By & To obtain \\
\hline Area & & \\
& acre & 4047 & square meter \\
& acre-foot (acre-ft) & 1233 & cubic meter
\end{tabular}

Density

pounds per cubic foot $\left(\mathrm{lbs} / \mathrm{ft}^{3}\right)$

pounds per cubic foot $\left(\mathrm{lbs} / \mathrm{ft}^{3}\right)$

Energy and Area per Unit Time

British thermal unit per square foot

$$
\text { per minute }\left[\left(\mathrm{Btu} / \mathrm{ft}^{2}\right) / \mathrm{min}\right]
$$

British thermal unit per square foot

$$
\text { per minute }\left[\left(\mathrm{Btu} / \mathrm{ft}^{2}\right) / \mathrm{min}\right]
$$

Length

$$
\begin{array}{r}
\text { foot }(\mathrm{ft}) \\
\text { inch } \\
\text { inch } \\
\text { mile (mi) }
\end{array}
$$

Mass

$$
\text { pound (lb) }
$$

0.3048

2.54

25.4

1.609

453.5

.06243

1054 gram per cubic meter

kilograms per cubic meter

watt per square meter

Joule meter

centimeter

millimeter

kilometer

\section{Specific Heat Capacity}

British thermal unit per pound

degree Fahrenheit $\left[\mathrm{Btu} /\left(\mathrm{lb}^{\circ} \mathrm{F}\right)\right]$

Pressure

$$
\begin{array}{r}
\text { inch of mercury (in. } \mathrm{Hg} \text { ) } \\
\text { millibar (mbar) }
\end{array}
$$

kilopascal ( $\mathrm{kPa})$

0.10

joule per kilogram degree kelvin $\left[\mathrm{j} /\left(\mathrm{kg}^{\circ} \mathrm{K}\right)\right]$

gram

Velocity

mile per hour $(\mathrm{mi} / \mathrm{h})$

Temperature: Degrees Fahrenheit $\left({ }^{\circ} \mathrm{F}\right)$ can be converted to degrees Celsius $\left({ }^{\circ} \mathrm{C}\right)$ by using the formula ${ }^{\circ} \mathrm{C}=\left[{ }^{\circ} \mathrm{F}-32\right] / 1.8$. Degrees Celsius $\left({ }^{\circ} \mathrm{C}\right)$ may be converted to degrees Kelvin $\left({ }^{\circ} \mathrm{K}\right)$ by using the formula ${ }^{\circ} \mathrm{K}={ }^{\circ} \mathrm{C}+273.16$.

Sea level: In this report, "sea level" refers to the National Geodetic Vertical Datum of 1929 (NGVD of 1929, formerly called "Sea-Level Datum of 1929"), which is derived from a general adjustment of the first-order leveling networks of the United States and Canada.

Note: Data tables in this report, including totals and mean values, are derived from computer spreadsheet programs. These programs display a defined number of digits following a decimal point, but retain the original number of digits in the spreadsheet cell. The displayed number is rounded appropriately. However, the full number of digits is used for any calculations, such as sums or means, and the resulting number may not be rounded to equal exactly the sum or mean of the displayed digits. Any discrepancy commonly will be in the least significant digit displayed. The sum or mean value as displayed is more precise than the sum or mean of the displayed cells value. 


\section{SYMBOLS USED IN TEXT}

C

$C_{s}$

$C_{w}$

$c_{p}$

$d$

$d_{f}$

$D_{b}$

$e_{1}, e_{2}$

E

G

H

K

$k$

$L$

$L E$

$R n$

$S_{S}$

$T_{1}, T_{2}$

$\mathrm{t}$

$u_{1}, u_{2}$

$W$

$z_{0}$

$z_{1}, z_{2}$

$\beta$

$\Delta \mathrm{e}$

$\Delta T$

$\Delta T_{s}$

$\gamma$

$\mathrm{f}_{\mathrm{h}}$

$\phi_{\mathrm{m}}$

$\psi_{\mathrm{m}}, \psi_{\mathrm{h}}$

$\rho$

$\theta_{1}, \theta_{2}$
Temperature, in degrees Celsius

Heat capacity of dry soil, $\mathrm{J} /\left(\mathrm{kg}^{\circ} \mathrm{C}\right)$

Heat capacity of water, $\mathrm{J} /\left(\mathrm{kg}^{\circ} \mathrm{C}\right)$

Specific heat at constant pressure, $\mathrm{J} /\left(\mathrm{kg}^{\circ} \mathrm{C}\right)$

Zero-plane displacement height, $\mathrm{m}$

Depth of burial of soil heat flux plate, $m$

Soil bulk density, $\mathrm{kg} / \mathrm{m}^{3}$

Vapor pressure at heights 1 and 2 above soil surface, $\mathrm{kPa}$

Evapotranspiration, $\mathrm{mm}$

Soil heat flux, $\mathrm{W} / \mathrm{m}^{2}$

Sensible heat flux, $\mathrm{W} / \mathrm{m}^{2}$

Temperature, in degrees Kelvin

Von Kárman's constant $=0.4$, dimensionless

Latent heat of vaporization, $\mathrm{J} / \mathrm{g}$

Latent heat flux, $\mathrm{W} / \mathrm{m}^{2}$

Net radiation, $\mathrm{W} / \mathrm{m}^{2}$

Heat storage in soil interval above soil heat flux plate, $\mathrm{W} / \mathrm{m}^{2}$

Air temperature at heights 1 and 2 above soil surface, ${ }^{\circ} \mathrm{C}$

Time sampling interval, $\mathrm{s}$

Windspeed at heights 1 and 2 above soil surface, $\mathrm{m} / \mathrm{s}$

Soil-water content, gravimetric

Roughness length, $\mathrm{m}$

Heights 1 and 2 above soil surface, $m$

Bowen ratio, dimensionless

Difference in vapor pressure, $\mathrm{kPa}$

Difference in air temperature, ${ }^{\circ} \mathrm{C}$

Difference in temperature of soil in interval above soil heat flux plate, ${ }^{\circ} \mathrm{C}$

Psychrometric constant, $\mathrm{kPa} /{ }^{\circ} \mathrm{C}$

Dimensionless potential temperature gradient

Dimensionless wind shear

Surface-layer stability corrector for momentum and heat, dimensionless

Density of air, $\mathrm{kg} / \mathrm{m}^{3}$

Potential temperature at heights 1 and 2 above soil surface, ${ }^{\circ} \mathrm{K}$ 


\title{
Estimated Ground-Water Discharge by Evapotranspiration, Ash Meadows Area, Nye County, Nevada, 1994
}

\author{
By William D. Nichols, Randell J. Laczniak, Guy A. DeMeo, and Timothy R. Rapp
}

\section{ABSTRACT}

Ground water discharges from the regional ground-water flow system that underlies the eastern part of the Nevada Test Site through numerous springs and seeps in the Ash Meadows National Wildlife Refuge in southern Nevada. The total spring discharge was estimated to be about 17,000 acre-feet per year by earlier studies. Previous studies estimated that about 10,500 acre-feet of this discharge was lost to evapotranspiration. The present study was undertaken to develop a more rigorous approach to estimating ground-water discharge in the Ash Meadows area. Part of the study involves detailed field investigation of evapotranspiration. Data collection began in early 1994. The results of the first year of study provide a basis for making preliminary estimates of ground-water discharge by evapotranspiration. An estimated 13,100 acre-feet of ground water was evapotranspired from about 6,800 acres of marsh and saltgrass. An additional 3,500 acre-feet may have been evapotranspired from open water and from about 1,460 acres of other areas of Ash Meadows in which field studies have not yet been made.

\section{INTRODUCTION}

Ground water discharges from the Ash Meadows subbasin of the Death Valley ground-water flow system (fig. 1) at more than 30 springs and seeps (Winograd and Thordarson, 1975, p. C78) in the Ash Meadows National Wildlife Refuge (fig. 2) in southern Nevada. The refuge is in the Amargosa Desert Hydrographic Area $^{1}$ (fig. 1) of the Mojave Desert and includes about
21,850 acres of desert uplands and spring-fed oases. The springs and seeps in the Refuge are an area of major discharge of ground water that flows beneath the eastern part of the Nevada Test Site toward Death Valley (fig. 1).

Ground water leaves the Ash Meadows subbasin through a combination of springflow, surface discharge, evapotranspiration, ground-water underflow, and pumped ground water. Quantifying each of these components of discharge is difficult because of the problems associated with their direct measurement. Springflow is the only component that has been measured directly thus far, and this has been measured only intermittently at large springs. Discharge from small springs and seeps is difficult or impossible to measure. Outflow to surface drainages is dispersed over many small channels and is difficult to measure because volumes are small and flow is intermittent. Evapotranspiration is a large component of ground-water discharge, especially in areas of shallow ground water. This component is the least quantified by direct measurement because of the difficulties in collecting the required data.

Estimating ground-water discharge on the basis of a summation of the components is complicated further by the interactions that occur between and among components. Some spring discharge returns to the shallow ground-water system, where it is discharged as evapotranspiration or as outflow to the

\footnotetext{
${ }^{1}$ Formal hydrographic areas in Nevada were delineated systematically by the U.S. Geological Survey and Nevada Division of Water Resources in the late 1960 's for scientific and administrative purposes (Rush, 1968; Cardinalli and others, 1968). The official hydrographic area names, numbers, and geographic boundaries continue to be used in Geological Survey scientific reports and Division of Water Resources administrative activities.
} 


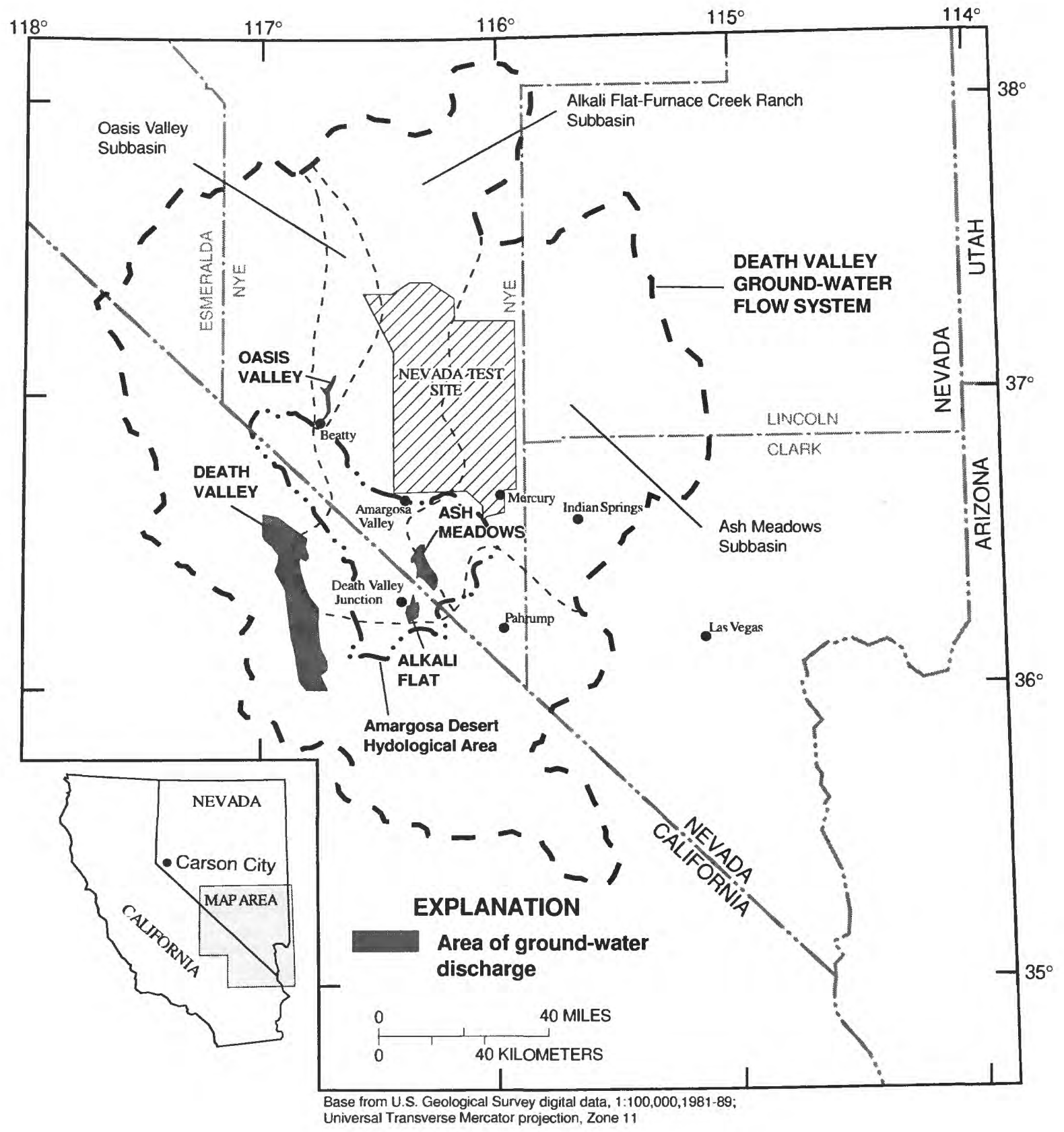

Figure 1. Location of Ash Meadows, Nevada Test Site, and Death Valley ground-water flow system in southern Nevada and southeastern California. Flow system and subbasin boundaries generalized from Laczniak and others (1996). 


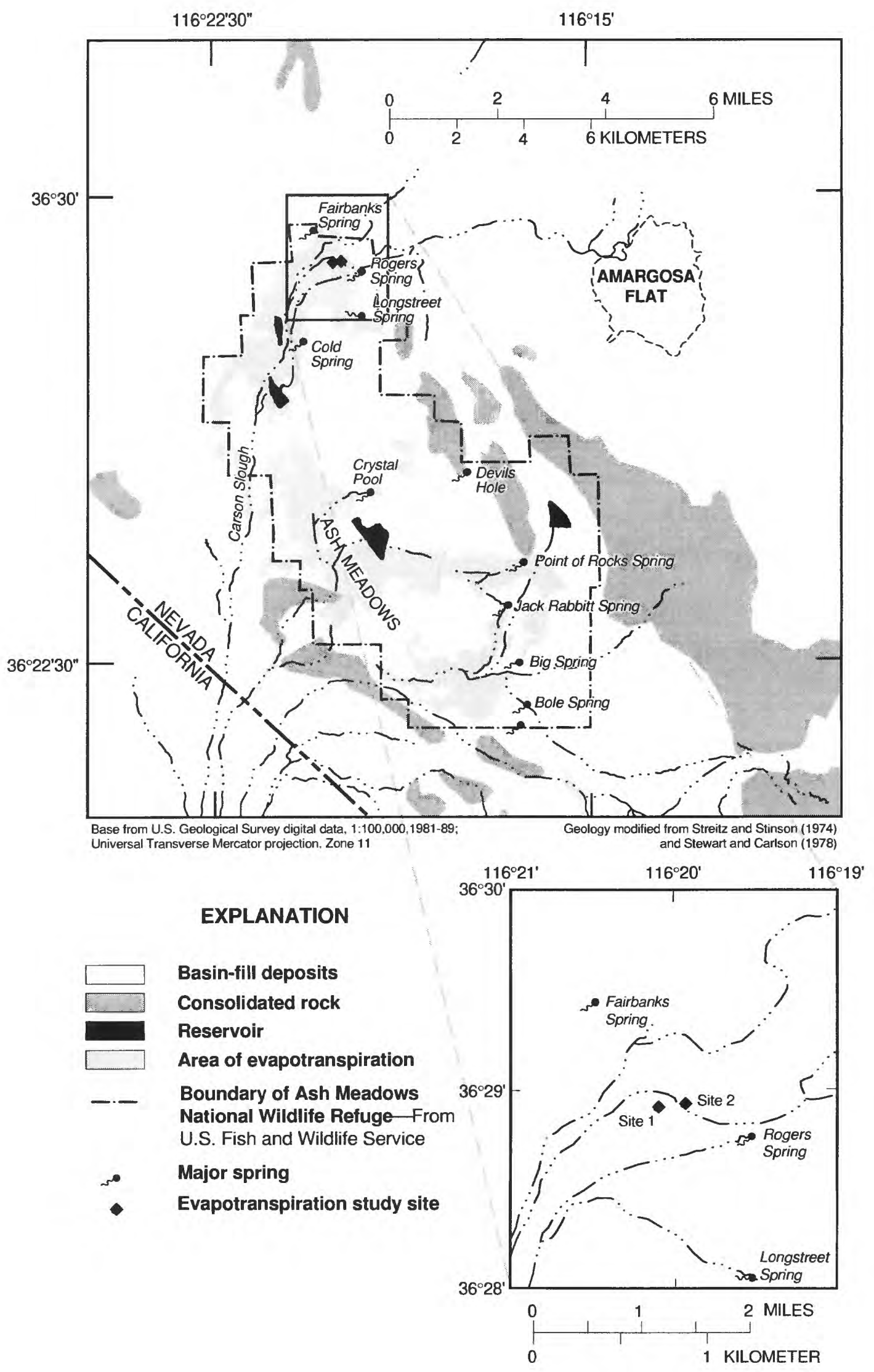

Figure 2. Location of Ash Meadows National Wildlife Refuge, Rogers Spring, and field study sites. 
surface drainage system. This surface outflow also may evapotranspire or may again infiltrate to the shallow ground-water system.

Spring discharge of ground water in the Ash Meadows area was estimated to be about 17,000 acre$\mathrm{ft}$ per year (Walker and Eakin, 1963, p. 24), on the basis of measurements made at large springs in 1953 and 1962. Additionally, ground-water discharge through evapotranspiration by phreatophytes at Ash Meadows is estimated to be about 10,500 acre-ft (Winograd and Thordarson, 1975, p. C84). This implies that about 6,500 acre-ft of spring discharge (1) returns to the shallow ground-water system and leaves the area as underflow or (2) is lost to surface discharge. Subsequent studies have relied on these estimates, and any refinement of the estimates requires that the interactions among the several components be better understood and that individual components be quantified more accurately.

This study was undertaken to develop a greater understanding of ground-water flow beneath the Nevada Test Site by quantifying ground-water discharge in the Ash Meadows area. The main focus of the study is to develop a more rigorous and comprehensive estimate of ground-water discharge in the Ash Meadows area by evapotranspiration. The study is being made in cooperation with the U.S. Department of Energy under Interagency Agreement AI0891 NV11040.

\section{Purpose and Scope of This Report}

This report presents the results of evapotranspiration field studies made in 1994 at two sites near Rogers Spring in the northern part of the Ash Meadows area. Ground-water discharge estimates are developed for the vegetation and depth-to-ground water conditions at the study sites. The estimated rates of ground-water discharge are then extended to other areas of Ash Meadows with similar conditions to provide preliminary estimates of ground-water discharge by evapotranspiration from the Ash Meadows area.

\section{Study Area}

Energy budget measurements were made in areas of saltgrass and saltgrass/wiregrass marsh near Rogers Spring, which is near the northern boundary of the Ash
Meadows National Wildlife Refuge (fig. 2) about $90 \mathrm{mi}$ west-northwest of Las Vegas, Nev., about 25 mi northwest of Pahrump, Nev., and about 29 mi east of Death Valley, Calif. Two field sites about 2,000 ft west-northwest of Rogers Spring were selected at which to install equipment to collect the micrometeorological data needed to calculate land-surface energy budgets and to estimate evapotranspiration.

Site 1 is at lat $36^{\circ} 28^{\prime} 56^{\prime \prime} \mathrm{N}$., long $116^{\circ} 19^{\prime} 56^{\prime \prime} \mathrm{W}$., at an altitude of about $2,255 \mathrm{ft}$ above sea level. The land-surface cover at this site is about 45 percent bare soil and about 55 percent sparse saltgrass and scattered patches of dense saltgrass (Distichlis spicata var. stricta). The saltgrass was about 7 inches high. The ground-water level at the site was $2.6 \mathrm{ft}$ below land surface on May 19, 1994, when the first piezometer was installed. Water levels had declined to $7.4 \mathrm{ft}$ below land surface by September 16 and had recovered to $1.5 \mathrm{ft}$ below land surface by December 31, 1994.

Site 2 is about $250 \mathrm{ft}$ east of Site 1 at lat $36^{\circ} 28^{\prime} 55^{\prime \prime} \mathrm{N}$., long $116^{\circ} 20^{\prime} 06^{\prime \prime} \mathrm{W}$., and is at an altitude of about 2,252 ft. This site is in a saltgrass/wiregrass marsh. The percentage of the surface covered by saltgrass (Distichlis spicata var. stricta) ranges from about 0 to 90 percent and by wiregrass (Juncus sp.) ranges from 5 to 100 percent. In the immediate area of the micrometeorological equipment, land-surface cover is about 90 percent saltgrass, 5 percent wiregrass, and 5 percent bare soil. The saltgrass was about 10 inches high and the wiregrass was about 16 inches high. Ground water was at land surface in January 1994; about $0.4 \mathrm{ft}$ below land surface on May 20; and about $4.6 \mathrm{ft}$ below land surface on September 7. The level had recovered to about $0.25 \mathrm{ft}$ below land surface by December 31, 1994.

\section{Climatic Setting}

Long-term climatic data for the Ash Meadows area are not available. The nearest U.S. Weather Service stations are Amargosa Farms, Nev. (lat 36² $34^{\prime} \mathrm{N}$., long $116^{\circ} 28^{\prime} \mathrm{W}$.), about $10 \mathrm{mi}$ north of Ash Meadows at an altitude of $2,450 \mathrm{ft}$; Pahrump, Nev. (lat $36^{\circ} 12^{\prime} \mathrm{N}$., long $115^{\circ} 59^{\prime} \mathrm{W}$.), about $15 \mathrm{mi}$ southeast of Ash Meadows at an altitude 2,670 ft; and Death Valley (Furnace Creek Ranch), Calif. (lat $36^{\circ} 28^{\prime} \mathrm{N}$., long $116^{\circ} 52^{\prime} \mathrm{W}$.), about $29 \mathrm{mi}$ west of Ash Meadows at an altitude of $-194 \mathrm{ft}$. Climatic data for these stations are summarized in table 1. 
Table 1. Climatic data for U.S. Weather Service stations near Ash Meadows and U.S. Geological Survey stations at Rogers Spring

\begin{tabular}{|c|c|c|c|c|c|}
\hline \multirow{2}{*}{ Station } & \multirow{2}{*}{$\begin{array}{c}\text { Annual } \\
\text { precipitation } \\
\text { (inches) }\end{array}$} & \multicolumn{3}{|c|}{ Temperature (degrees Fahrenheit) } & \multirow[b]{2}{*}{ Period } \\
\hline & & $\begin{array}{c}\text { Annual mean } \\
\text { daily }\end{array}$ & $\begin{array}{l}\text { Monthly mean } \\
\text { maximum }\end{array}$ & $\begin{array}{l}\text { Monthly mean } \\
\text { minimum }\end{array}$ & \\
\hline Amargosa Farms & 4.65 & 64.8 & $103.2^{\mathrm{a}}$ & $29.1^{\mathrm{b}}$ & $1965-90$ \\
\hline Pahrump & 4.09 & 61.4 & $101.5^{\mathrm{a}}$ & $26.2^{\mathrm{c}}$ & $1948-90$ \\
\hline Death Valley & 2.28 & 76.7 & $114.9^{\mathrm{a}}$ & $38.5^{b}$ & $1961-90$ \\
\hline Rogers Spring 1 & $1.1^{\mathrm{d}}$ & 64.6 & $105.0^{\mathrm{e}}$ & $27.7^{\mathrm{c}}$ & 1994 \\
\hline Rogers Spring 2 & $1.1^{\mathrm{d}}$ & 59.9 & $102.8^{\mathrm{a}}$ & $28.1^{c}$ & 1994 \\
\hline
\end{tabular}

Data collected as part of this study in 1994 provide some insight into climatic conditions at Ash Meadows, although only for 1994 (Nichols and Rapp, 1996), for comparison with the longer record at the Weather Service stations. For 1994, the mean daily temperature at Ash Meadows was about $62^{\circ} \mathrm{F}$, the mean daily relative humidity was about 33 percent, and the mean daily windspeed was about $3.5 \mathrm{mi} / \mathrm{h}$. The coolest month was December with a mean daily temperature of about $42^{\circ} \mathrm{F}$ and a minimum daily temperature of about $28^{\circ} \mathrm{F}$; mean daily humidity in December was about 52 percent. July and August were the warmest months with mean daily temperatures of about $88^{\circ} \mathrm{F}$ and maximum daily temperatures of about $104^{\circ} \mathrm{F}$. Mean daily relative humidity in July and August was somewhat higher at Site 2, averaging about 24 percent, than at Site 1 , where it averaged about 22 percent, reflecting the wetter surface conditions of the saltgrass/wiregrass marsh. Minimum daily relative humidity, which occurs between noon and 6:00 p.m., was about 7 percent at Site 1 and about 11 percent at Site 2 .

Precipitation in the Ash Meadows area was estimated to be about 1.1 inches in 1994. Equipment malfunctions throughout the year precluded measurement of precipitation at the Rogers Spring sites. Precipitation for the site, instead, was estimated from precipitation data collected 8.4 mi southwest of Rogers Spring at the U.S. Geological Survey streamflow and precipitation gage on the Amargosa River. The gage is $1.6 \mathrm{mi}$ south of the California-Nevada State line near California State Route 127. Total precipitation recorded at this site from December 27, 1993, to January 5, 1995, was 2.17 inches. At least an inch of this is believed to have fallen during the storms of January 1-5, 1995.

\section{EVAPOTRANSPIRATION AND GROUND- WATER DISCHARGE}

\section{Estimates for Rogers Spring Sites}

\section{Methods and Equations}

Data collected at the two field-study sites were used to calculate energy budgets at each site from which evapotranspiration was estimated. The evapotranspiration rates, thus determined, provided estimates of daily, monthly, and annual evapotranspiration rates at each site, which are believed to be representative of other areas of Ash Meadows with similar vegetation and depths to ground water. These estimated rates for the Rogers Spring sites were used to estimate ground-water evapotranspiration rates for other areas of Ash Meadows at which field studies have not yet been done.

Field instrumentation and methods are described by Nichols and Rapp (1996). Collection of some micrometeorological data began in mid-December 1993. Collection of detailed vapor pressure and temperature gradient data needed for calculation of evapotranspiration began on March 16, 1994, and continued through December 31, 1994. The following is a discussion of the methods and equations used to solve the energy budget equation and estimate evapotranspiration.

Values of net radiation, air temperature gradient, vapor pressure gradient, and soil heat flux are used to solve the energy budget equation, given by

$$
R n=L E+H+G
$$


using the Bowen-ratio method (Tanner, 1960). (Symbols used in the equations in this report are given in the table on p. vii.)

Net radiation, $R n$, and soil heat flux, $G$, are measured. Latent heat flux, $L E$, and sensible heat flux, $H$, are not measured and equation 1 cannot be solved directly; the Bowen-ratio method (Bowen, 1926) is used. The Bowen ratio is the ratio of sensible to latent heat fluxes and is given by

$$
\beta=\frac{H}{L E}=\gamma \frac{\Delta T}{\Delta e}=\gamma \frac{T_{1}-T_{2}}{e_{1}-e_{2}} .
$$

Latent heat flux, $L E$, is calculated by substituting equation 2 into equation 1 so that

$$
L E=\frac{R n-G}{1+\beta} .
$$

Then from equation 2 , sensible heat flux, $H$, is given by

$$
H=\beta L E .
$$

Measured soil heat flux must be corrected for heat stored in the soil interval above the buried heat flux transducer. This correction is given by

$$
S_{s}=\frac{\Delta T_{s}}{t} d_{f} D_{b}\left(C_{s}+W C_{w}\right) .
$$

Some conditions exist for which the solution of the energy balance equation yields estimates of latent heat flux, and hence evapotranspiration, that are in error. Some problems are inherent to all methods of solving the energy balance equation. In addition, errors in the measurement of net radiation, soil heat flux, and other micrometeorological quantities are caused by instrument error or bias. The error estimation of latent heat flux as a result of measurement errors is discussed by Fuchs and Tanner (1970).

Errors also result from application of the Bowenratio method (Ohmura, 1982). Several problems that result in incorrect or inappropriate values for the Bowen ratio typically occur during early morning and late afternoon hours when the nocturnal inversion is dissipating or forming, and during precipitation. First, inaccurate measurement of net radiation or soil heat flux during early morning or late afternoon hours may result in a negative value for available energy $(R n-G)$ that leads to a negative value for latent heat flux even though the vapor pressure gradient indicates a positive flux. Under these conditions, the Bowen ratio is correct, but the calculated flux value has the wrong sign. Second, as the nocturnal inversion dissipates or forms, the Bowen ratio, $\beta$, approaches -1 and the latent heat flux, as calculated by equation 3 , approaches positive or negative infinity even for small values of available energy. Finally, the precision of the instrument used to measure vapor pressure may be exceeded, for which condition the calculated vapor pressure gradient may be incorrect. In all the above described errors, the Bowen ratio was rejected and sensible heat flux for that time interval was estimated using temperature and wind gradients, or profiles, and is given by Arya (1988, p. 172)

$$
H=\frac{\rho c_{p} k^{2}\left(u_{1}-u_{2}\right)\left(\theta_{2}-\theta_{1}\right)}{\phi_{m} \phi_{h}\left(\ln \frac{\left(\left(z_{2}-d\right) / z_{0}\right)-\psi_{m}}{\left(\left(z_{1}-d\right) / z_{0}\right)-\psi_{m}}\right)}
$$

Latent heat flux then was calculated as the residual, $L E=R n-G-H$.

Latent heat flux is converted to inches of evapotranspiration using the following equation:

$$
\mathrm{ET}=\frac{\mathrm{LE}}{\mathrm{L}}\left(3.37 \times 10^{3}\right),
$$

where

ET is evaporation, in inches, and

$3.37 \times 10^{3}$ is the factor to convert $\mathrm{LE} / \mathrm{L}$ from metric units to inches.

Daily evapotranspiration was estimated by solving the energy budget equation for each 20 -minute data-averaging interval and averaging the results for the 24-hour period (figs. 3 and 4; tables 2 and 3). Daily mean net radiation also is plotted in figures 3 and 4 to show the strong correlation between net radiation and evapotranspiration. Values of evapotranspiration for the first 74 days of the year, for which no data are available, were estimated using values of evapotranspiration for the last 74 days plotted in figures 3 and 4 . Values of evapotranspiration missing for several days for which data were lost have been interpolated on the basis of estimated evapotranspiration values on preceding and following days. 


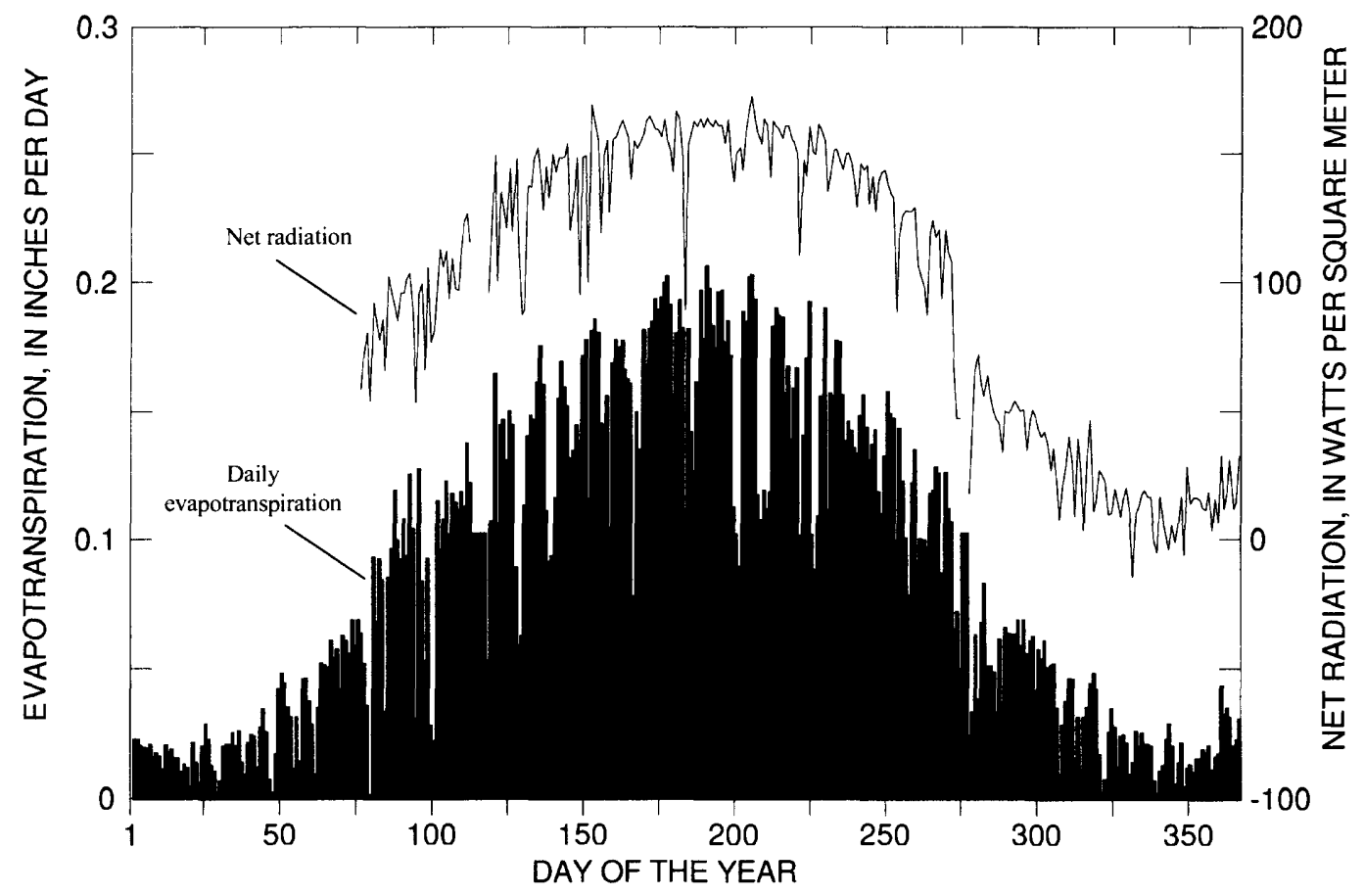

Figure 3. Daily evapotranspiration and daily mean net radiation, Rogers Spring Site 1, 1994.

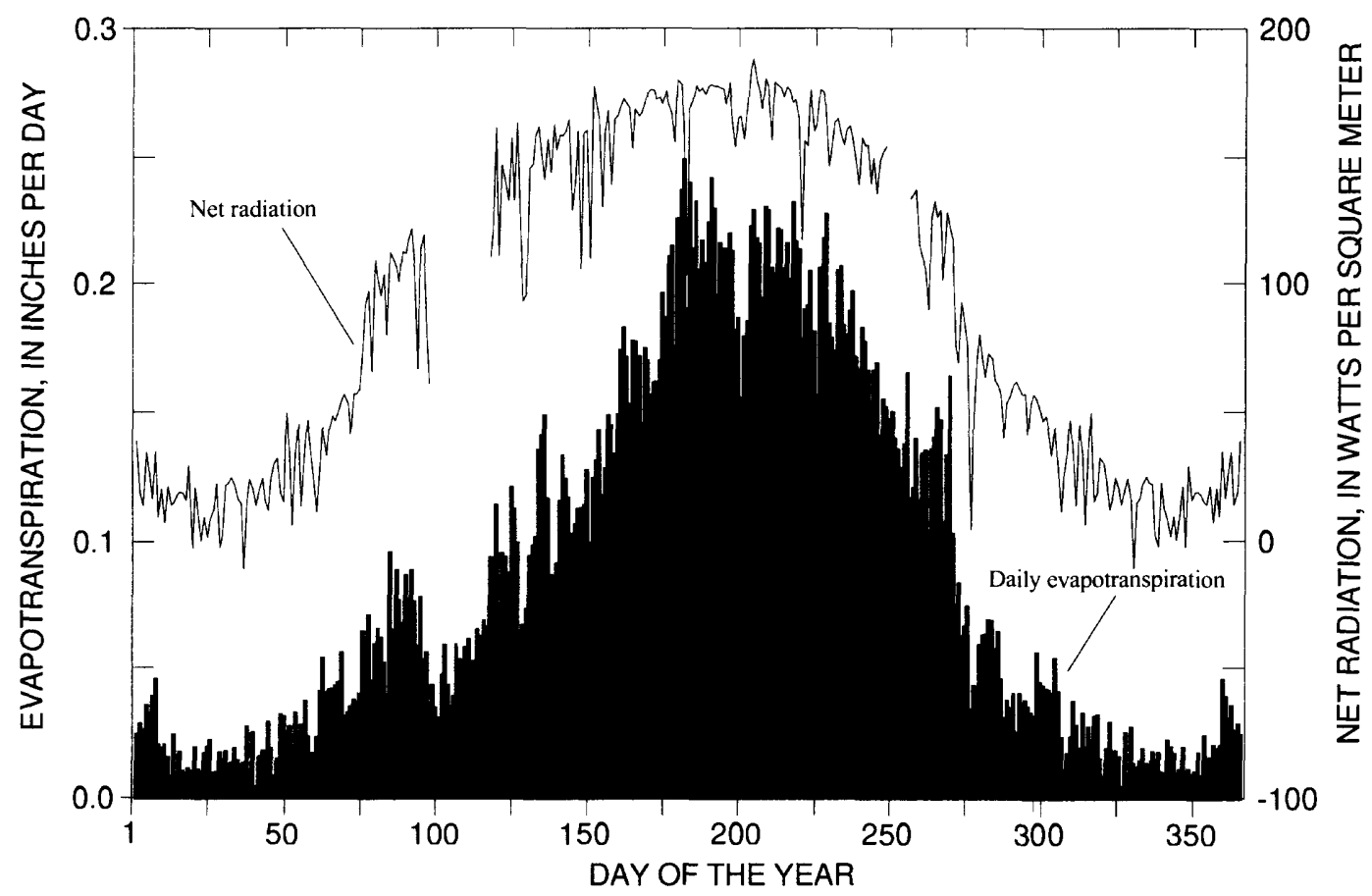

Figure 4. Daily evapotranspiration and daily mean net radiation, Roger Spring Site 2, 1994. 


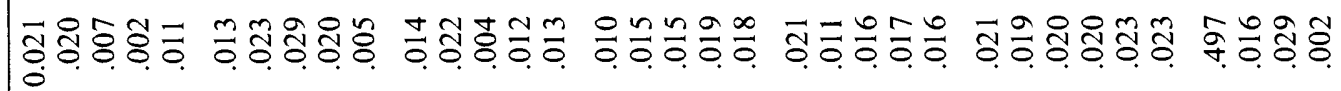

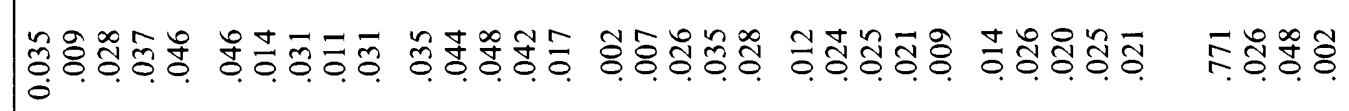

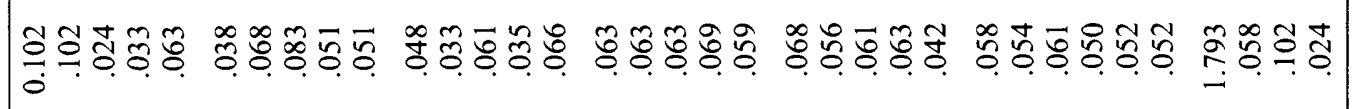

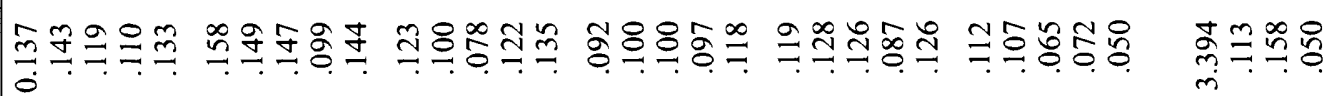

क्⿹

직 웜ำ

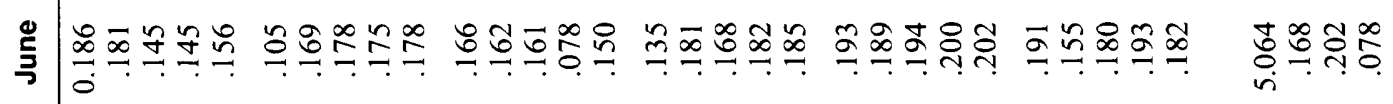

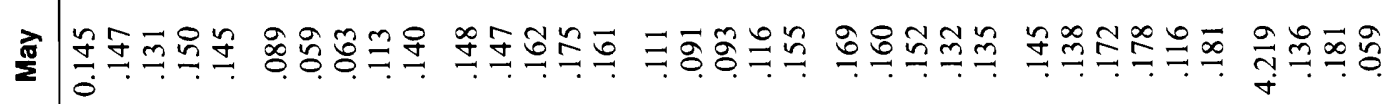

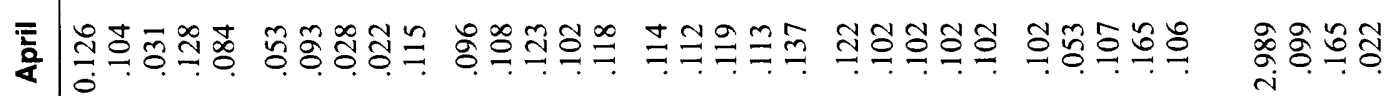

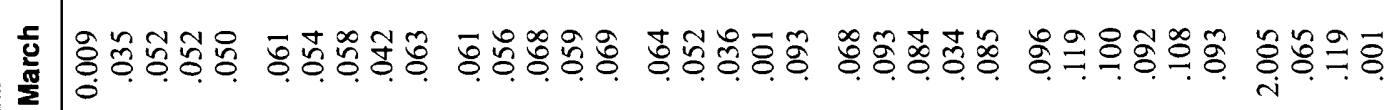

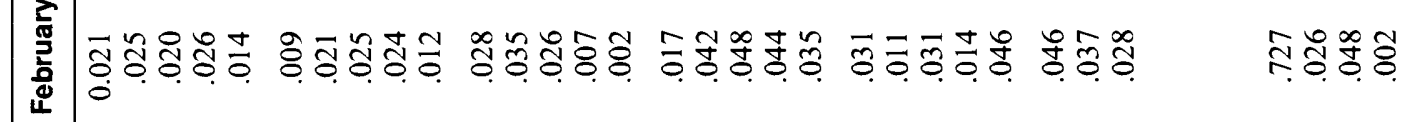
蛋 


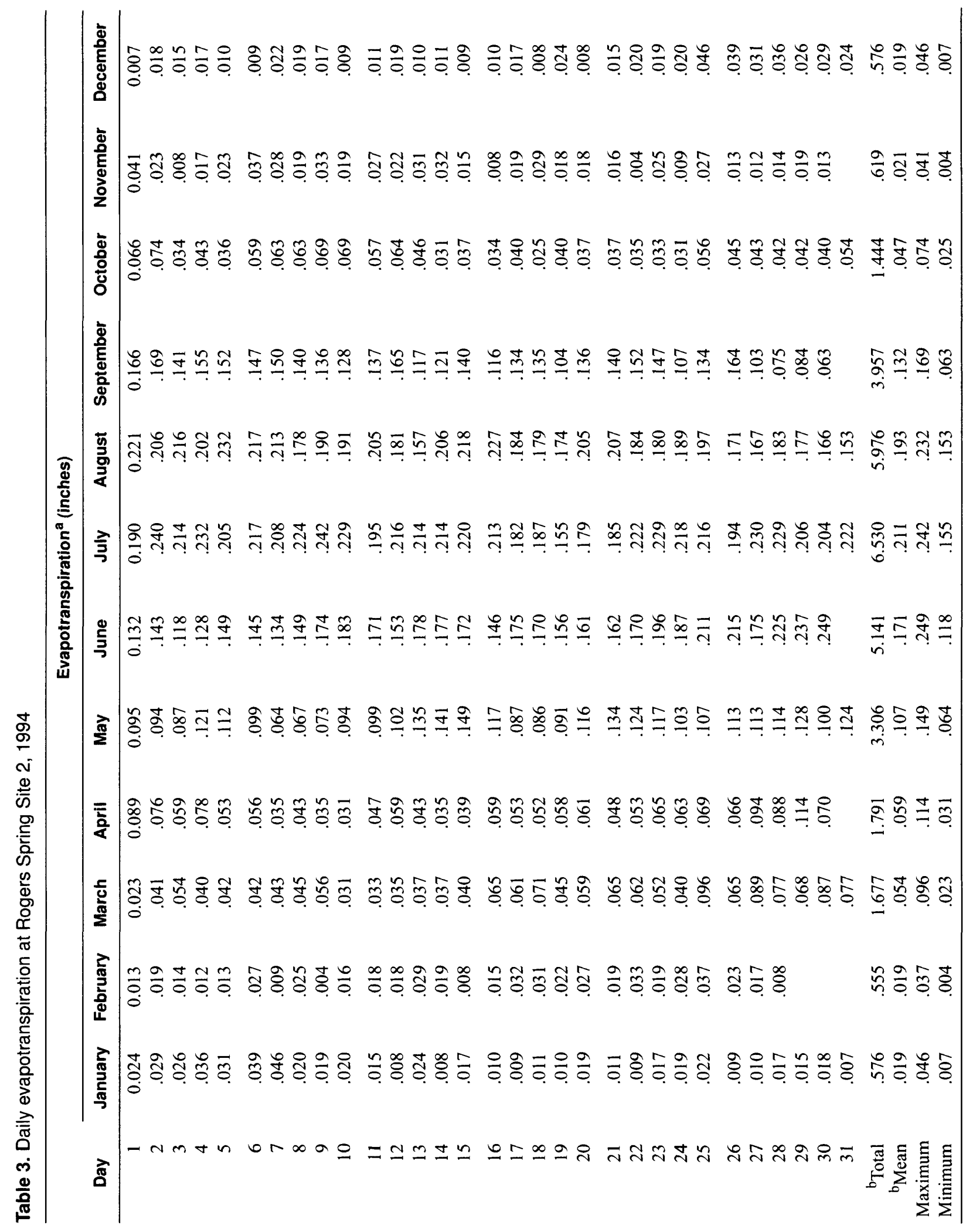




\section{Results}

Daily estimated evapotranspiration at Site 1 ranged from $0.001 \mathrm{in} / \mathrm{d}$ in March to $0.206 \mathrm{in} / \mathrm{d}$ in July, and averaged $0.0865 \mathrm{in} / \mathrm{d}$ for the year (table 2). At Site 2 , it ranged from a minimum of $0.004 \mathrm{in} / \mathrm{d}$ in February and November to a maximum of $0.249 \mathrm{in} / \mathrm{d}$ at the end of June, and averaged $0.0880 \mathrm{in} / \mathrm{d}$ for the year (table 3 ). Annual evapotranspiration was estimated to be 31.59 inches at Site 1 and 32.15 inches at Site 2 (tables 2, 3, and 4).

Table 4. Annual total and annual mean, maximum, and minimum daily evapotranspiration, Rogers Spring Sites 1 and 2, 1994

\begin{tabular}{lcc}
\hline & \multicolumn{2}{c}{ Evapotranspiration (inches) } \\
\cline { 2 - 3 } & Site 1 & Site 2 \\
\hline Annual total & 31.59 & 32.15 \\
Annual mean daily & .0865 & .0880 \\
Annual maximum daily & .206 & .249 \\
Annual minimum daily & .001 & .004 \\
\hline
\end{tabular}

In spite of the significant difference in the percent of vegetation between the two sites, the annual evapotranspiration from each site is similar. A comparison of monthly mean daily evapotranspiration rates and monthly evapotranspiration totals for the two sites (tables I and 2, fig. 5) shows that evapotranspiration increased more rapidly in the spring at Site 1 than at Site 2 . The saltgrass at Site 1 was a vigorous green by mid-May; at Site 2 it did not become green and show evidence of growth until late May, although the wiregrass became green much earlier. The difference in evapotranspiration at the two sites during this time reflects the greater evaporation of shallow ground water from bare soil and somewhat greater transpiration from saltgrass at Site 1. Dormant vegetation at Site 2 formed an insulating cover that shaded and reduced evaporation from the underlying soil. By July and August, the higher percentage of vegetation at Site 2 is reflected in the greater daily and monthly evapotranspiration. Evapotranspiration at Site 1 also exceeded that at Site 2 from October to the end of the year, again reflecting the shading of soil by dormant vegetation at Site 2.

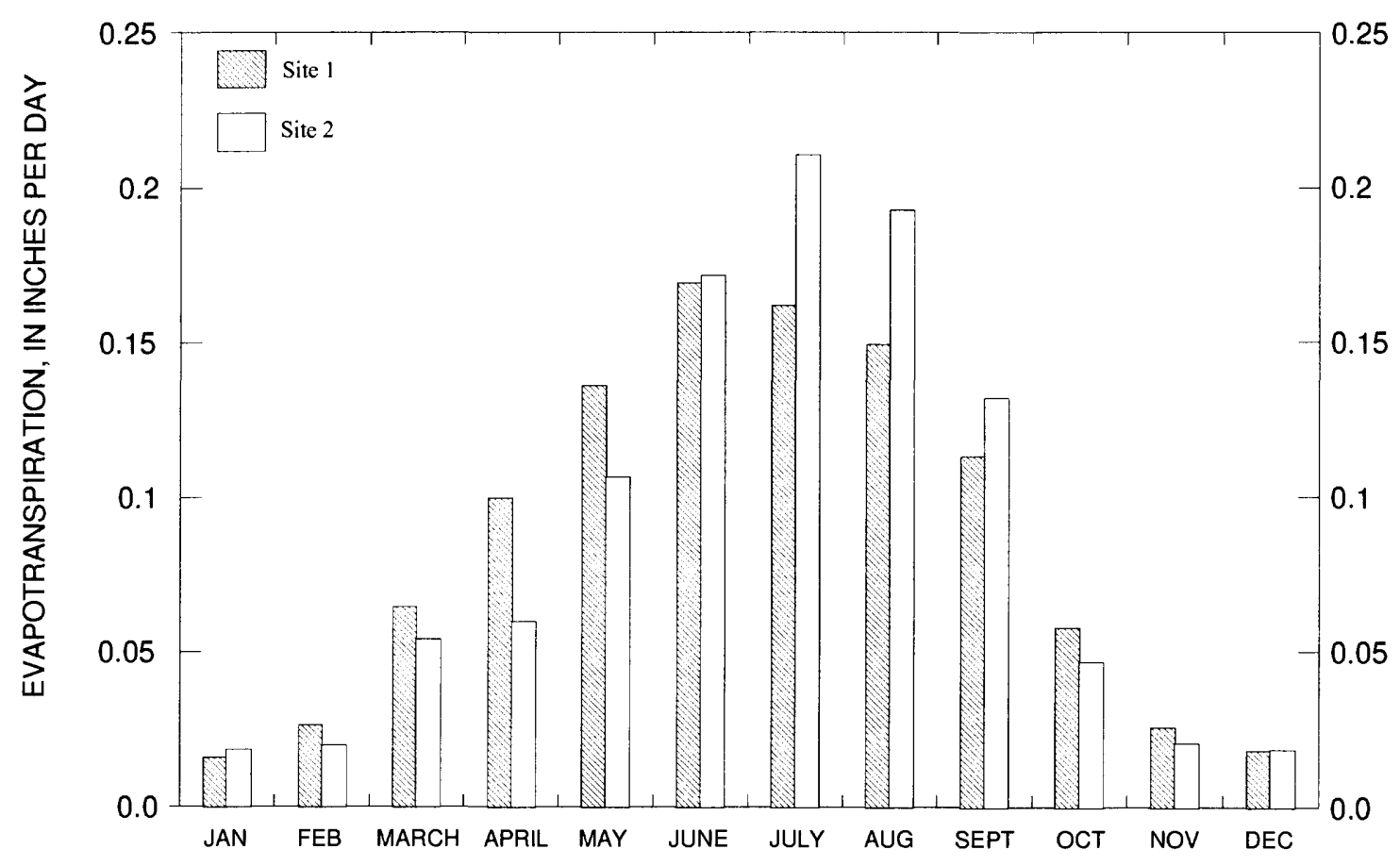

Figure 5. Monthly mean daily evapotranspiration, Rogers Spring, Sites 1 and 2, 1994. 
The greater evaporation from soil at Site 1 as compared with Site 2 is reflected in the greater changes in soil moisture at Site 1. Volumetric soil-water content decreased from 21.0 percent on March 3 at Site 1 to 2.9 percent by July 18 , a change of about 18 percent. At Site 2, soil-water content was 30.0 percent on March 3 and had decreased to 22.7 percent by July 18 , a change of only about 8 percent. This approximately 10 -percent greater reduction in soil moisture at Site 1 would account only for about 0.1 to $0.2 \mathrm{ft}$ of the evapotranspiration at the site.

Annual ground-water discharge by evapotranspiration was about $2.5 \mathrm{ft}$ at Site 1 and about $2.6 \mathrm{ft}$ at Site 2 , nearly the same as total annual evapotranspiration, given the sparse estimated precipitation during the year. The additional water evaporated from soil moisture at Site 1, discussed above, was included as groundwater discharge because soil moisture was replenished by ground water later in the year.

\section{Preliminary Estimates for Ash Meadows Area}

Three different estimated rates of ground-water discharge for saltgrass and marsh grass in the Ash Meadows area and the Amargosa Desert were used by Walker and Eakin (1963, p. 23). They used a rate of 0.5 $\mathrm{ft} / \mathrm{yr}$ for areas of mesquite, saltgrass, and rabbitbrush with an average depth to ground water of $10 \mathrm{ft} ; 1.25$ $\mathrm{ft} / \mathrm{yr}$ for areas of saltgrass with ground water at depths between 0 and $5 \mathrm{ft}$; and $3.0 \mathrm{ft} / \mathrm{yr}$ for areas of marsh grass that are flooded by spring discharge (Walker and Eakin, 1963, p. 23). The study of Walker and Eakin (1963) is of the entire Amargosa Desert, and the specific areas to which they applied each of these estimated rates of ground-water discharge by evapotranspiration are not given. They applied the first estimated rate to 1,000 acres, the second estimated rate to 1,200 acres, and the third estimated rate to 3,000 acres to estimate a total ground-water discharge by evapotranspiration from the Amargosa Desert of 11,500 acre-ft. Ground-water discharge from the Ash Meadows area of the Amargosa Desert was estimated at 10,500 acre- $\mathrm{ft}$ by Winograd and Thordarson (1975, p. C84).

\section{A land-surface cover classification using} remotely-sensed data from Landsat satellite imagery is being developed as part of this study. The classification is intended to delineate areas of similar vegetation type and density. The methodology has been described by Arteaga and others (1995). Areas of similar vegetation type and density are assumed to discharge ground water by evapotranspiration at similar rates. Preliminary results of the classification analysis are used here to make initial estimates of ground-water discharge by evapotranspiration from Ash Meadows.

Preliminary analysis of Landsat data for September 1992 suggests that 8,260 acres of vegetation and bare soil discharge ground water by evapotranspiration (fig. 2; J. LaRue Smith, U.S. Geological Survey, written commun., 1994). An additional 160 acres of open water from spring discharge are subject to evaporation. Of the total area, about 660 acres are rush/wiregrass/saltgrass marsh with springtime water levels at land surface or, in some areas, standing water all year; about 1,250 acres are moderately dense to dense saltgrass or saltgrass/wiregrass areas with shallow water levels that are at or near land surface in the spring; and 4,880 acres are moderately dense saltgrass and other grasses with depths to ground water ranging from about 3 to about $10 \mathrm{ft}$. For purposes of this preliminary analysis, half of this area, 2,440 acres, is assumed to have had depths to ground water from 3 to 6 feet and half of the area is assumed to have had depths from 6 to $10 \mathrm{ft}$.

A ground-water discharge rate of about $2.6 \mathrm{ft} / \mathrm{yr}$ is considered to be generally representative of groundwater discharge by evapotranspiration from marsh areas and areas of moderately dense to dense saltgrass with depths to ground water from about 0 to $1 \mathrm{ft}$. This conclusion is based on the analysis of data collected at Site 2 during this study. A discharge rate of about $2.5 \mathrm{ft} / \mathrm{yr}$ on the basis of the analysis of data collected at Site 1 is considered to be representative of areas of moderately dense to dense saltgrass with depths to ground water from about 1 to $3 \mathrm{ft}$. For areas of moderately dense saltgrass with other grasses where depths to ground water are greater than about $3 \mathrm{ft}$, the rate of ground-water discharge is expected to be less than $2.5 \mathrm{ft}$. Estimated discharge rates of $2.1 \mathrm{ft}$ and $1.3 \mathrm{ft}$ for saltgrass evapotranspiration in areas where the depth to ground water is 3 to $6 \mathrm{ft}$ and 6 to $10 \mathrm{ft}$, respectively, are based on work in progress (William D. Nichols, U.S. Geological Survey, written commun., 1996).

The estimated rates for moderate and sparse saltgrass areas are based on the data from Site 1 (table 5). These estimates are uncertain and are expected to be refined by continuing field studies. Preliminary estimates of ground-water discharge from saltgrass in areas with varying depth to ground water and from saltgrass/wiregrass marshes in the Ash Meadows area are given in table 5 . 
Table 5. Estimated discharge of shallow ground water by evapotranspiration from marshes and saltgrass areas, Ash Meadows, 1994

\begin{tabular}{lcccc}
\hline \multicolumn{1}{c}{$\begin{array}{c}\text { Vegetation } \\
\text { type }\end{array}$} & $\begin{array}{c}\text { Depth to } \\
\text { water } \\
\text { (feet below } \\
\text { land surface) }\end{array}$ & $\begin{array}{c}\text { Area } \\
\text { (acres) }\end{array}$ & $\begin{array}{c}\text { Rate } \\
\text { (feet per } \\
\text { year) }\end{array}$ & $\begin{array}{c}\text { Discharge } \\
\text { (acre-feet } \\
\text { per year, } \\
\text { rounded) }\end{array}$ \\
\hline Marsh & $0-1$ & 660 & 2.6 & 1,720 \\
Saltgrass, dense & $1-3$ & 1,250 & 2.5 & 3,120 \\
Saltgrass, moderate & $3-6$ & $2,440^{\text {a }}$ & 2.1 & 5,120 \\
Saltgrass, sparse & $6-10$ & $2,440^{\text {a }}$ & 1.3 & 3,170 \\
\hline Total & & 6,790 & & 13,100 \\
\hline
\end{tabular}

a Estimated.

In the Ash Meadows area, about 1,310 acres of vegetated areas and about 150 acres of bare soil areas have shallow ground-water levels where estimates of ground-water discharge by evapotranspiration are not yet available, but from which as much as 2,500 acre- $\mathrm{ft}$ may be discharged. Continuing field studies are expected to provide the data needed to make more reliable estimates of discharge from these areas. Additionally, in 1992, about 160 acres of open water, either ponded spring discharge or ground-water discharge, were subject to evaporation. The variation in area of open water during the year and from one year to the next has not been determined. Open-water evaporation in this area of Nevada is estimated to be about $6 \mathrm{ft} / \mathrm{yr}$ (Scott, 1971). If the area of open water remained constant during the year and was the same in 1994 as 1992 , then another 1,000 acre-ft of ground water would have been lost by evaporation.

As a preliminary estimate, total ground-water discharge by evapotranspiration in the Ash Meadows area during 1994 may have been about 17,000 acre-ft.

\section{SUMMARY AND CONCLUSIONS}

Ground water discharges from the Ash Meadows subbasin of the Death Valley ground-water flow system at more than 30 springs and seeps in the Ash Meadows National Wildlife Refuge in southern Nevada. Spring discharge of ground water was estimated to be about $17,000 \mathrm{acre}-\mathrm{ft} / \mathrm{yr}$. Previous studies estimated that about 10,500 acre-ft of ground water was discharged through evapotranspiration by phreatophytes.

Ground water leaves the Ash Meadows subbasin as springflow, surface discharge, evapotranspiration, ground-water underflow, and pumped ground water. Evapotranspiration is a large component of ground- water discharge, especially in areas of shallow ground water, but is the component that has been the least quantified by direct measurement. The main focus of the study is to develop more rigorous and comprehensive estimates of ground-water discharge by evapotranspiration. Two field study sites near Rogers Spring were selected at which to install equipment needed to collect micrometeorological data for calculating landsurface energy budgets and to estimate evapotranspiration.

Daily estimated evapotranspiration at Site 1 ranged from $0.001 \mathrm{in} / \mathrm{d}$ in March to $0.206 \mathrm{in} / \mathrm{d}$ in July, and averaged $0.0865 \mathrm{in} / \mathrm{d}$ for the year. At Site 2 , it ranged from $0.004 \mathrm{in} / \mathrm{d}$ in February and November to $0.249 \mathrm{in} / \mathrm{d}$ in late June, and averaged $0.0880 \mathrm{in} / \mathrm{d}$ for the year. Annual evapotranspiration was estimated to be 31.59 inches at Site 1 and 32.15 inches at Site 2. For 1994, annual ground-water discharge by evapotranspiration at the two sites - about $2.5 \mathrm{ft}$ at Site 1 and about $2.6 \mathrm{ft}$ at Site 2 - is nearly the same as total annual evapotranspiration, given the sparse estimated precipitation of about $0.1 \mathrm{ft}$ during the year.

These estimates of ground-water discharge by evapotranspiration are believed to be representative of about 1,910 acres of marsh and saltgrass area at Ash Meadows with depths to ground water less than $3 \mathrm{ft}$ below land surface. Also, these estimates provide the basis for estimating ground-water discharge from 4,880 acres of saltgrass with depths to ground water greater than $3 \mathrm{ft}$. The acreages and land cover are based on preliminary analysis of Landsat satellite data.

Ground-water discharge by evapotranspiration from these areas of marsh and saltgrass is estimated to be about 13,100 acre-ft. Another 1,000 acre-ft may be evaporated from open-water surfaces and perhaps as much as 2,500 acre-ft may be discharged by evapotranspiration from areas for which evapotranspiration rates have not yet been determined from field studies. Annual ground-water discharge by evapotranspiration in the Ash Meadows area may be as much as 17,000 acre-ft. All this evapotranspiration is from shallow ground water and spring discharge.

\section{REFERENCES CITED}

Arteaga, F.E., Smith, J.L., and Harrill, J.R., 1995, Irrigated croplands, estimated pumpage, and water-level changes in Diamond Valley, Eureka and Elko Counties, Nevada, through 1990: U.S. Geological Survey Open-File Report 95-107, 68 p. 
Arya, S.P., 1988, Introduction to micrometeorology: New York, Academic Press, 303 p.

Bowen, I.S., 1926, The ratio of heat losses by conduction and by evaporation by any water surface: Physics Review, v. 27, p. 779-787.

Cardinalli, J.L., Roach, L.M., Rush, F.E., and Vasey, B.J., comps., 1968, State of Nevada hydrographic areas: Nevada Division of Water Resources map, scale $1: 500,000$.

Fuchs, M., and Tanner, C.B., 1970, Error analysis of Bowen ratios measured by differential psychrometry: Agricultural Meteorology, p. 329-334.

Laczniak, R.J., Cole, J.C., Sawyer, D.A., and Trudeau, D.A., 1996, Summary of hydrogeologic controls on groundwater flow at the Nevada Test Site, Nye County, Nevada: U.S. Geological Survey Water-Resources Investigations Report 96-4109, 59 p.

Nichols, W.D., and Rapp, T.R., 1996, Micrometeorological data for energy budget and climate studies near Rogers Spring, Ash Meadows National Wildlife Refuge, Nye County, Nevada, 1994: U.S. Geological Survey OpenFile Report 96-170, 49 p.
Ohmura, Atsumu, 1982, Objective criteria for rejecting data for Bowen ratio flux calculations: Journal of Applied Meteorology, p. 595-598.

Rush, F.E., 1968, Index of hydrographic areas in Nevada: Nevada Division of Water Resources, Information Report 6, $38 \mathrm{p}$.

Scott, B.R., ed., 1971, Average annual evaporation: Nevada Division of Water Resources map, scale 1:2,000,000.

Tanner, C.B., 1960, Energy balance approach to evapotranspiration from crops: Soil Science Society Proceedings, v. 24 , p. 1-9.

Walker, G.E., and Eakin, T.E., 1963, Geology and ground water of Amargosa Desert, Nevada-California: Nevada Department of Conservation and Natural Resources, Ground-Water Resources - Reconnaissance Report 14, $45 \mathrm{p}$.

Winograd, I.J., and Thordarson, William, 1975, Hydrogeologic and hydrochemical framework, south-central Great Basin, Nevada-California, with special reference to the Nevada Test Site: U.S. Geological Survey Professional Paper 712-C, $126 \mathrm{p}$. 